\title{
A novel serum index for accurate diagnosis of spontaneous bacterial peritonitis in cirrhotic patients without other infections
}

\author{
Hany M. Elsadek ${ }^{1 *}$, Soha A. Elhawari ${ }^{2}$ and Ahmed Mokhtar ${ }^{3}$
}

\begin{abstract}
Background: The accurate non-invasive diagnosis of spontaneous bacterial peritonitis (SBP) in patients with decompensated liver cirrhosis has not been achieved yet. The aim of the study was to obtain an unmistakable diagnosis of SBP using a new simple serum bioscore, made by combined measurement of procalcitonin (PCT), erythrocyte sedimentation rate (ESR), and C-reactive protein (CRP), which we called the PEC index. This crosssectional analytic study comprised 178 cirrhotic patients with ascites (60 patients with SBP and 118 patients with sterile ascites), after excluding non-SBP infection, during the period from March 2019 until September 2019. In all participants, serum levels of PCT, ESR, and CRP were measured, and PEC index was calculated [PEC index $=$ PCT $\times$ $(E S R+C R P)]$.

Results: Patients with SBP $(n=60)$ had significantly higher serum PEC index than those with sterile ascites $(n=118)$ (41.0/31.2-93.0 vs. 9.9/5.9-15.0, $P<0.001)$. PEC index distinguished culture positive cases significantly $(P<0.001)$. Using receiver operating characteristic (ROC) statistics, the sensitivity and specificity of $P C T$, at a cutoff value of $0.590 \mathrm{ng} / \mathrm{mL}$, for SBP diagnosis, were $81.67 \%$ and $93.33 \%$, respectively (area under the curve $[A \cup C]=0.879 ; 95 \%$ confidence interval [Cl] 0.809-0.948). The sensitivity and specificity of ESR, at a cutoff value of $27.0 \mathrm{~mm} / \mathrm{hour}$, were $73.33 \%$ and $61.67 \%$, respectively ( $\mathrm{AUC}=0.679 ; 95 \% \mathrm{Cl} 0.581-0.776)$. The sensitivity and specificity of CRP, at a cutoff value of $21.0 \mathrm{mg} / \mathrm{L}$, were $93.33 \%$ and $51.67 \%$, respectively (AUC $=0.736 ; 95 \% \mathrm{Cl} 0.639-0.833$ ). While, the sensitivity and specificity of PEC index, at a cutoff value of 20, were highest (98.33\% and 96.67\%, respectively, AUC $=0.977 ;$; 95\% Cl 0.940-0.996).

Conclusion: Serum PEC index makes an accurate noninvasive diagnosis of SBP, after excluding other infections.

Keywords: Cirrhosis, Spontaneous bacterial peritonitis, Procalcitonin, PEC index
\end{abstract}

\section{Background}

Spontaneous bacterial peritonitis (SBP) is the commonest life-threatening infection encountered in cirrhotic patients with ascites. It accounts for more than half of all infections [1-3].The outpatient prevalence of SBP is $1.5-3.5 \%$ and exceeds $10 \%$ in hospitalized patients $[4,5]$.

The immune dysfunction in decompensated cirrhotic patients (DCPs) along with vulnerability of gut mucosa leading to translocation of bacteria and bacterial endotoxins from bowel lumen into ascitic fluid (AF), underlie the pathogenesis of SBP $[1,6-8]$.

\footnotetext{
* Correspondence: hanyelsadek75@yahoo.com

${ }^{1}$ Gastroenterology \& Hepatology Unit, Internal Medicine Department, Faculty of Medicine, Zagazig University, Zagazig, Egypt

Full list of author information is available at the end of the article
}

SBP precipitates several other complications of cirrhosis, e.g., impairment of hepatic status, hepatic encephalopathy, worsening of coagulopathy, variceal bleeding, renal failure, and even death [9]. In former decades, SBP was associated with $>90 \%$ mortality that has been reduced nowadays to $\sim 20 \%$ with the development of prompt diagnosis and appropriate therapy $[9,10]$.

Typically, SBP presents with abdominal pain and tenderness associated with fever. However, it may present with other local symptoms and signs of peritonitis as vomiting, and ileus; other manifestations of systemic inflammation as hypothermia, chills, tachycardia, tachypnea, and shock; worsening of liver or kidney functions; or hepatic encephalopathy [11]. SBP may also be asymptomatic in $10 \%$ of cases [4]. 
Though, a positive AF culture for a pathogen is the gold standard for SBP diagnosis, about $60 \%$ of cases with clinical manifestations indicative of SBP and increased AF polymorphonuclear leukocytic (PMNL) count have negative cultures. Consequently, an AF PMNL count $\geq$ $250 / \mu \mathrm{L}$ is considered for SBP diagnosis, regardless of culture results [12-15]. In considerable number of cases, the absence of typical clinical characteristics of SBP makes its identification difficult [16].Therefore, an early non-invasive diagnosis of SBP in DCPs is sometimes recommended, especially in cases with irrelevant clinical manifestations, those newly admitted to hospital, or those with unexplained shock or deterioration of their liver functions $[2,3,16]$.

Several non-invasive methods were tried in many studies for SBP diagnosis, as alternatives to diagnostic paracentesis, with variable accuracies, e.g., clinical scores [17], fecal calprotectin [18], and numerous serum inflammatory cytokines and chemokines such as monocyte chemotactic protein-1, interleukin-10 [19], human neutrophil peptide [20], platelet indices [21], macrophage inflammatory protein-1 beta [22], interferon- $\gamma$-induced protein-10, tumor necrosis factor- $\alpha$, and interleukin- 6 [23]. However, none of these methods was accurate enough to replace diagnostic paracentesis.

Procalcitonin (PCT) is a 116-amino acid polypeptide precursor of calcitonin with a molecular weight of $13 \mathrm{KDa}$ produced by extra-thyroidal cells (e.g., monocytes) [24]. It has been proposed in highly cited studies as a potentially valuable serum biomarker to diagnose bacterial infections in general [24-26] and SBP in particular [27-30]. Normally, serum PCT level is undetectable $(<0.01 \mathrm{ng} / \mathrm{mL})$, and it rapidly increases in case of infection [26].

Although the reported average estimate of sensitivity and specificity of serum PCT for SBP diagnosis in different clinical trials were relatively high ( $83 \%$ and $92 \%$, respectively) [27], this performance was insufficient to make an acceptable accurate diagnosis. In order to achieve a more reliable diagnostic accuracy of PCT, we have tried a combined measurement of serum PCT with serum erythrocyte sedimentation rate (ESR) and Creactive protein (CRP) to formulate a novel serum index for SBP diagnosis that we called, the PEC index.

\section{Methods}

\section{Study design and sitting}

This cross-sectional analytic study was carried out on 178 consecutive hospitalized cirrhotic patients with ascites admitted to internal medicine and tropical medicine departments, in collaboration with the Clinical Pathology Department, Faculty of Medicine, Zagazig University Hospital, Egypt, from March 2019 until September 2019.

\section{Participants}

Out of 257 consecutive hospital admissions of potentially eligible cirrhotic patients with ascites, 62 patients who had non-SBP infections were excluded and 7 patients died before the sampling procedures. Eligibility for the study was confirmed in 188 patients; of them, only 178 patients accepted to participate in the study.

\section{Inclusion criteria}

1. Adult patients $\geq 18$ years

2. All consecutive hospitalized DCPs with moderate to severe ascites (that was detected clinically and confirmed with abdominal ultrasonography) who were admitted for different purposes like clinically suspected SBP, variceal bleeding, and hepatic encephalopathy. Participants were classified into an SBP group (either symptomatic or asymptomatic) $(n=60)$ and a sterile ascites group $(n=118)$.

The diagnosis of SBP was confirmed by an AFPMNL count $\geq 250 / \mathrm{mm}^{3}$ with or without a positive ascitic fluid culture for pathogenic bacteria. Absence of both criteria meant the ascites was sterile $[14,15]$.

\section{Exclusion criteria}

1. Patients with a diagnosed infection other than $\mathrm{AF}$ infection, e.g., upper and lower respiratory tract infection, urinary tract infection, and otitis media

2. Patients with HCC or associated pancreatic disease, as these conditions could affect the components of PEC index.

3. Patients who received antibiotics 10 days prior to hospital admission.

4. Patients with AF culture positivity and AF PMNL count $<250 / \mathrm{mm}^{3}$ (bacterascites)

5. Patients who refused to be enrolled in the study or refused to sign the consent.

\section{Study tools}

All included patients were subjected to thorough clinical assessment, abdominal ultrasound scanning, routine laboratory examination, e.g., complete blood picture, liver function and kidney function tests, coagulation profile and viral markers, and determination of serum levels of ESR (first hour), CRP (by Cobas 8000, Roch, Germany) and $\mathrm{PCT}$, and peritoneal fluid examination.

\section{Serum PCT measurement}

This was done by the electrochemiluminescence immunoassay (ECLIA) on Cobas e 411 immunoassay analyzers, Roch, Germany, acting via the sandwich principle. The analyzer automatically calculates the analyte concentration 
of each sample in $\mathrm{ng} / \mathrm{ml}$ with a measuring range of 0.02 to $100 \mathrm{ng} / \mathrm{ml}$ and the coefficient of variability of $8 \%$ [31].

\section{Peritoneal fluid examination technique}

Sterile bedside diagnostic paracentesis was done using a 23-G needle attached to a $20 \mathrm{cc}$ syringe after applying local anesthesia. Then, aspirated ascitic fluid was collected into two tubes and analyzed within $2 \mathrm{~h}$ of aspiration. The first tube for culture and sensitivity and second tube with ethylene diamine tetraacetic acid were to be analyzed for biochemistry and leukocyte counts.

\section{PEC index}

This is a new serum bioscore, innovated in this study, which was calculated by the formula; PEC index $=$ PCT $\times(E S R+C R P)$. This formula was chosen on a statistical base, after repeated trials and errors while trying several different formulae.

\section{Statistical analysis}

Statistical analysis was performed with SPSS software, version 22.0 (SPSS Inc., Chicago, IL, USA). The continuous variables were expressed as means \pm standard deviation (SD) and the categorical variables as count numbers and proportions. The suitable test was used, e.g., Student's $t$ test, Mann-Whitney $U$ test, Pearson's chi-squared test, Fisher's exact test, and Pearson's correlation test. The result was considered significant if $P \leq$ 0.05 . In order to test the diagnostic accuracy of various markers as well as the novel PEC index for diagnosis of SBP, we used receiver operating characteristic (ROC) statistics and determined sensitivity, specificity, and area under the curve (AUC) for each.

\section{Results}

Comparison between SBP group $(n=60)$ and sterile ascites group $(n=118)$ regarding demographic, clinical, and laboratory characteristics revealed significantly higher serum PCT, ESR, and CRP, as well as significantly higher AF LDH and PMNL count in SBP group $(P<$ 0.001, for all parameters). Also, PEC index was significantly higher in SBP group than in sterile ascites group (41.0/31.2-93.0 vs. 9.9/5.9-15.0, $P<0.001$ ) (Table 1 ).

AF bacterial culture positivity was found in $41.67 \%$ $(25 / 60)$ of SBP group, but not in sterile ascites group at all (0/60) (Table 1). The commonest pathogens encountered were Escherichia coli in $68.0 \%(17 / 25)$ and Klebsiella in $16.0 \%(4 / 25)$ of culture positive cases. Positivity of AF culture among patients with SBP was significantly associated with higher levels of serum PCT, PEC index, AF LDH, and AF PMNL count and with lower AF glucose level $(P<0.001$, for all) (Table 2$)$.

ROC statistics were used to assess diagnostic accuracy of tested serum markers in SBP diagnosis (Figs. 1 and 2).
The sensitivity and specificity of PCT, at a cutoff value of $0.590 \mathrm{ng} / \mathrm{mL}$, were $81.67 \%$ and $93.33 \%$ (AUC $=0.879$; 95\% confidence interval [CI] 0.809-0.948). The sensitivity and specificity of ESR, at a cutoff value of $27.0 \mathrm{~mm} / \mathrm{h}$, were $73.33 \%$ and $61.67 \%$ (AUC $=0.679$; 95\% CI $0.581-$ 0.776). The sensitivity and specificity of CRP, at a cutoff value of $21.0 \mathrm{mg} / \mathrm{L}$, were $93.33 \%$ and $51.67 \%$ (AUC = 0.736; 95\% CI 0.639-0.833) (Fig. 1 and Table 3). Serum PEC index, at a cutoff value of 20, had much higher sensitivity and specificity for SBP diagnosis $(98.33 \%$ and 96.67\%, respectively, AUC $=0.977 ; 95 \%$ CI 0.940-0.996), with an overall diagnostic accuracy of $97.50 \%$ (Fig. 2 and Table 3).

Figures 3 and 4 and Table 3 show the diagnostic performances of PEC index and its components in discrimination between cases with culture-negative SBP and those with sterile ascites. PCT, at a cutoff value of 0.305 $\mathrm{ng} / \mathrm{mL}$, was associated with a better diagnostic accuracy $(\mathrm{AUC}=0.825 ; 95 \%$ CI $0.742-0.907)$ than that of ESR, at a cutoff value of $27 \mathrm{~mm} / \mathrm{h}$ (AUC $=0.649 ; 95 \%$ CI $0.521-$ 0.776 ) and that of CRP at a cutoff value of $23.5 \mathrm{mg} / \mathrm{L}$ $(\mathrm{AUC}=0.704 ;$ 95\% CI 0.613-0.794) (Fig. 3). PEC index, at a cutoff value of 20, was associated with the best diagnostic performance (AUC $=0.970 ; 95 \%$ CI $0.934-1.0$ ) (Fig. 4).

\section{Discussion}

The search for a non-invasive and readily available biomarker for unmistakable diagnosis of SBP in cirrhotic patients with ascites, is still under clinical trials $[22,23$, $29,30,32,33]$. The current work, to the best of our knowledge, is the first to characterize the use of indexed combined measurement of serum PCT, ESR, and CRP for this purpose, after exclusion of non-SBP bacterial infections.

In this study, all SBP patients $(n=60)$ had AF inflammatory response due to bacterial infection as was identified by AF PMNL count $\geq 250 / \mathrm{HPF}$. Other biochemical findings in AF analysis confirmed the presence of infection like high LDH and low glucose. These findings were in accordance with that of Badawy et al. [34] and ELMotasem et al. [35].

In addition, serum levels of acute phase reactants; ESR, CRP, and PCT in the SBP group of our patients (31/23-36 mm/h, 27/24-29 $\mathrm{mg} / \mathrm{L}$, and 0.691/0.604$1.690 \mathrm{ng} / \mathrm{mL}$, respectively) were significantly higher than in sterile ascites group $(25 / 19-30 \mathrm{~mm} / \mathrm{h}, 20 / 11-25 \mathrm{mg} /$ $\mathrm{L}$, and $0.259 / 0.159-0.350 \mathrm{ng} / \mathrm{mL}$, respectively) $(P<$ 0.001, for all). Likewise, Viallon et al. [36], Such et al. [37], Papp et al. [38], and Wu et al. [39] described elevations of inflammatory mediators in the setting of SBP. This could be explained by activation of cytokine synthesis and innate immunity in response to circulating bacterial endotoxins [40]. 
Table 1 Demographic, clinical, and laboratory data of the studied groups

\begin{tabular}{|c|c|c|c|}
\hline & Sterile ascites $n=118$ & $\mathrm{SBP} n=60$ & $P$ \\
\hline Age (mean $\pm S D$, years) & $57.3 \pm 7.3$ & $57.6 \pm 6.8$ & 0.824 \\
\hline Male sex & $55(46.6 \%)$ & $38(63.3 \%)$ & 0.073 \\
\hline Hypertension & $12(10.2 \%)$ & $9(15.0 \%)$ & 0.345 \\
\hline Diabetes mellitus & $18(15.3 \%)$ & $11(18.3 \%)$ & 0.599 \\
\hline Cause of liver disease & & & $0.727^{* *}$ \\
\hline - HCV infection & $94(79.7 \%)$ & $51(85.5 \%)$ & \\
\hline - HBV infection & $20(16.9 \%)$ & $8(13.3 \%)$ & \\
\hline - Other causes & $4(3.4 \%)$ & $1(1.7 \%)$ & \\
\hline Serum albumin (mean $\pm \mathrm{SD}, \mathrm{g} / \mathrm{dL}$ ) & $2.53 \pm 0.18$ & $2.49 \pm 0.21$ & 0.178 \\
\hline Serum Total bilirubin (median/IQR, mg/dL) & $2.11 / 0.91-3.29$ & $2.00 / 1.50-3.42$ & $0.167^{*}$ \\
\hline INR $($ mean $\pm S D)$ & $1.47 \pm 0.20$ & $1.53 \pm 0.28$ & 0.095 \\
\hline ALT (median/IQR, IU/L) & 27/18-38 & $34 / 15-44$ & $0.387^{*}$ \\
\hline AST (median/IQR, IU/L) & $48 / 36-60$ & $47 / 29-74$ & $0.892^{*}$ \\
\hline Serum creatinine (median/IQR, mg/dL) & $1.00 / 1.00-1.00$ & $1.00 / 1.00-1.75$ & $0.158^{*}$ \\
\hline Serum LDH (mean $\pm S D, I U / L)$ & $214 \pm 54$ & $226 \pm 51$ & 0.126 \\
\hline Blood TLC (median/IQR, $\times 10^{3} / \mathrm{mm}^{3}$ ) & $6.10 / 4.00-8.00$ & $7.00 / 4.43-8.90$ & $0.158^{*}$ \\
\hline Hemoglobin (mean $\pm \mathrm{SD}, \mathrm{g} / \mathrm{dL}$ ) & $10.07 \pm 1.49$ & $10.06 \pm 1.33$ & 0.952 \\
\hline Platelets count (median $/ \mathrm{IQR}, \times 10^{3} / \mathrm{mm}^{3}$ ) & $90 / 66-144$ & $82 / 66-144$ & $0.550^{*}$ \\
\hline ESR (median/IQR, mm/hour) & 25/19-30 & $31 / 23-36$ & $<0.001^{*}$ \\
\hline CRP (median/lQR, mg/L) & $20 / 11-25$ & $27 / 24-29$ & $<0.001^{*}$ \\
\hline $\mathrm{PCT}$ (median/IQR, ng/mL) & $0.259 / 0.159-0.350$ & $0.691 / 0.604-1.690$ & $<0.001^{*}$ \\
\hline PEC index $[P C T \times(E S R+C R P)]($ median/lQR $)$ & $9.89 / 5.93-15.00$ & $41.04 / 31.18-92.99$ & $<0.001^{*}$ \\
\hline Ascitic fluid albumin (mean $\pm \mathrm{SD}, \mathrm{g} / \mathrm{dL}$ ) & $0.837 \pm 0.148$ & $0.875 \pm 0.128$ & 0.094 \\
\hline Ascitic fluid glucose (mean $\pm \mathrm{SD}, \mathrm{g} / \mathrm{dL}$ ) & $112 \pm 17$ & $99 \pm 12$ & $<0.001$ \\
\hline Ascitic fluid LDH (mean \pm SD, IU/L) & $109 \pm 18$ & $157 \pm 42$ & $<0.001$ \\
\hline Ascitic fluid PMNL (median/IQR, cell/mm³) & 200/170-207 & $3334 / 274-641$ & $<0.001^{*}$ \\
\hline Ascitic fluid PMNL $\geq 250 / \mathrm{mm}^{3}$ & $0(0.0 \%)$ & $60(100.0 \%)$ & $<0.001$ \\
\hline Positive ascitic fluid bacterial culture & $0(0.0 \%)$ & $25(41.7 \%)$ & $<0.001$ \\
\hline
\end{tabular}

$S D$ standard deviation, $I Q R$ interquartile range, $H C V$ hepatitis $C$ virus, $H B V$ hepatitis $B$ virus, INR international normalized ratio, $A L T$ alanine aminotransferase, $A S T$ aspartate aminotransferase, IU international unit, $L D H$ lactate dehydrogenase, $T L C$ total leukocytic count, ESR erythrocyte sedimentation rate, $C R P C$-reactive protein, $P C T$ procalcitonin, PMNL polymorphonuclear leukocytes

*Mann-Whitney $U$ test, ${ }^{* *}$ Fisher's exact test

As a pro-inflammatory cytokine, PCT is elevated in acute bacterial infections and reaches the highest serum level in severe infections and sepsis as it is enhanced by systemic inflammatory response. It is not elevated by viral infection or autoimmune inflammation [24-26]. Serum PCT measurement has an established role in differentiation between bacterial infections and other inflammatory conditions [25, 41]; however, its use as a diagnostic biomarker for SBP has been reported frequently in the last decade, with conflicting results [22, 27-30,38,39].

In this work, with the exception that CRP was more sensitive than PCT for SBP diagnosis $(93.33 \%$ versus $81.67 \%$, respectively), the sensitivity and specificity of serum PCT at a cutoff value of $0.590 \mathrm{ng} / \mathrm{mL}$ for SBP diagnosis $(81.67 \%$ and $93.33 \%$, respectively, AUC: 0.879$)$ were relatively higher than that of ESR at a cutoff value of $27.0 \mathrm{~mm} / \mathrm{h}(73.33 \%$ and $61.67 \%$, respectively, AUC 0.679 ) and that of CRP at a cutoff value $>21.0 \mathrm{mg} / \mathrm{L}$ (93.33\% and 51.67\%, respectively; AUC 0.736). PCT appears to be superior in detecting septic conditions to other pro-inflammatory markers like ESR and CRP, because of its earlier increase upon infection and its better specificity $[36,38,39,41]$.

A previous meta-analysis by Yang et al. [27] including18 studies on 1827 DCPs, published between 2000 and 2014, investigated the diagnostic performance of PCT as a marker of SBP. They reported a relatively good diagnostic performance with a summary estimate of sensitivity and specificity of $83.0 \%$ and $92.0 \%$, respectively, 
Table 2 Comparison between culture-positive and culture-negative SBP patients, regarding serum and AF biomarkers

\begin{tabular}{|c|c|c|c|}
\hline & $\begin{array}{l}\text { Culture negative } \\
n=35\end{array}$ & $\begin{array}{l}\text { Culture-positive } \\
n=25\end{array}$ & $P$ \\
\hline ALT (median/IQR, IU/L) & $38 / 15-45$ & $26 / 15-39$ & $0.413^{*}$ \\
\hline AST (median/IQR, IU/L) & $44 / 31-74$ & $48 / 22-79$ & $0.554^{*}$ \\
\hline Serum LDH (mean $\pm S D, I U / L)$ & $225 \pm 46$ & $229 \pm 58$ & 0.750 \\
\hline Blood TLC (median/IQR, $\times 10^{3} / \mathrm{mm} 3$ ) & 7.0/4.8-9.0 & 7.0/4.3-8.6 & $0.553^{*}$ \\
\hline Platelets count (median/IQR, $\times 10^{3} / \mathrm{mm}^{3}$ ) & $82 / 66-145$ & $80 / 68-133$ & $0.887^{*}$ \\
\hline ESR (median/IQR, mm/hour) & $32 / 22-36$ & $30 / 28-35$ & $0.952^{*}$ \\
\hline CRP (median/IQR, mg/L) & $26 / 24-28$ & $27 / 25-30$ & 0.253 \\
\hline $\mathrm{PCT}$ (median/IQR, ng/mL) & $0.614 / 0.410-0.649$ & $1.733 / 1.256-2.500$ & $<0.001^{*}$ \\
\hline $\mathrm{PEC}$ index $[\mathrm{PCT} \times(\mathrm{ESR}+\mathrm{CRP})]($ median/IQR) & $36.34 / 25.22-40.19$ & 101.48/70.79-136.89 & $<0.001^{*}$ \\
\hline Ascitic fluid albumin (mean $\pm \mathrm{SD}, \mathrm{g} / \mathrm{dL}$ ) & $0.865 \pm 0.13$ & $0.889 \pm 0.13$ & 0.467 \\
\hline Ascitic fluid glucose (mean $\pm \mathrm{SD}, \mathrm{g} / \mathrm{dL}$ ) & $104 \pm 9$ & $93 \pm 13$ & $<0.001$ \\
\hline Ascitic fluid LDH (mean $\pm S D$, IU/L) & $142 \pm 28$ & $177 \pm 50$ & $<0.001$ \\
\hline Ascitic fluid PMNL (median/IQR, cell/mm³) & $275 / 260-310$ & $655 / 463-6700$ & $<0.001^{*}$ \\
\hline
\end{tabular}

$S D$ standard deviation, IQR interquartile range, $A L T$ alanine aminotransferase, $A S T$ aspartate aminotransferase, $L D H$ lactate dehydrogenase, $T L C$ total leukocytic count, ESR erythrocyte sedimentation rate, CRP C-reactive protein, $P C T$ procalcitonin, $P M N L$ polymorphonuclear leukocytes

*Mann-Whitney $U$ test

which came very close to our results. On the other hand, Lesińska et al. [22] reported that serum PCT could not distinguish patients with and without SBP. The small sample size $(n=32)$ of their study [22] could explain this contradictory result.

Positive results of AF bacterial cultures, in this study, were found only in $41.6 \%(25 / 60)$ of SBP patients. Nearly the same result was frequently reported before $[12,14,15]$. The predominance of gram-negative over gram-positive bacteria among culture positive cases, in our study, goes

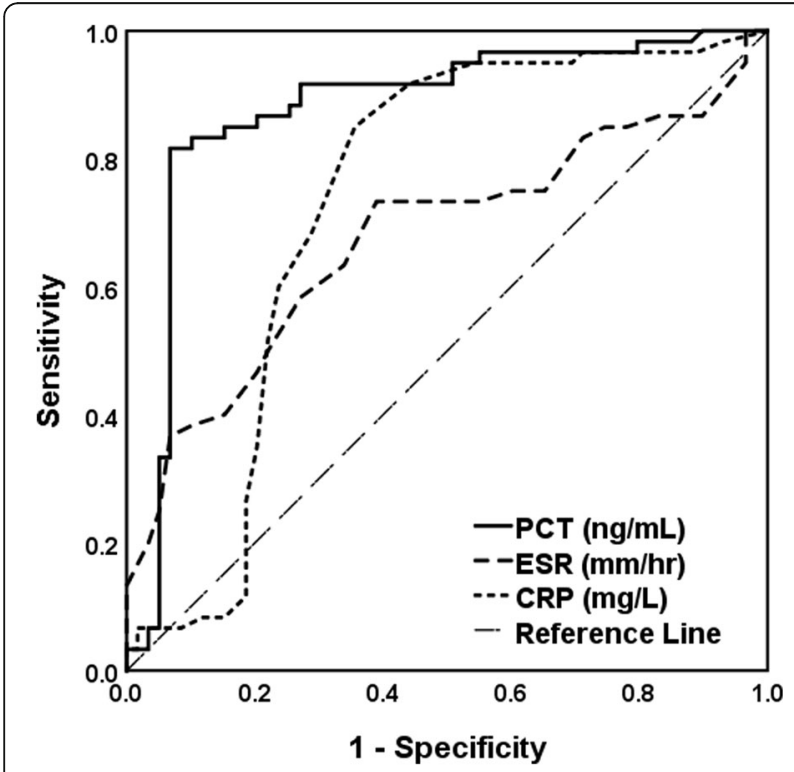

Fig. 1 Sensitivities and specificities of serum markers; ESR, CRP and $\mathrm{PCT}$ for SBP diagnosis with other studies [1, 42]. In the current work, serum PCT, opposite to ESR and CRP, was significantly elevated in culture positive cases of SBP $(P<0.001)$. This comes in accordance with the study of Cekin et al. [43], but it does not come in agreement with the studies of EL-Gendy et al. [44] or Cai et al. [28] who reported the lack of sensitivity of serum PCT to differentiate the culture results in SBP patients.

In this research, the newly advocated PEC index [calculated as PCT $\times(E S R+C R P)]$ was significantly higher in SBP group than in sterile ascites group $(P<0.001)$,

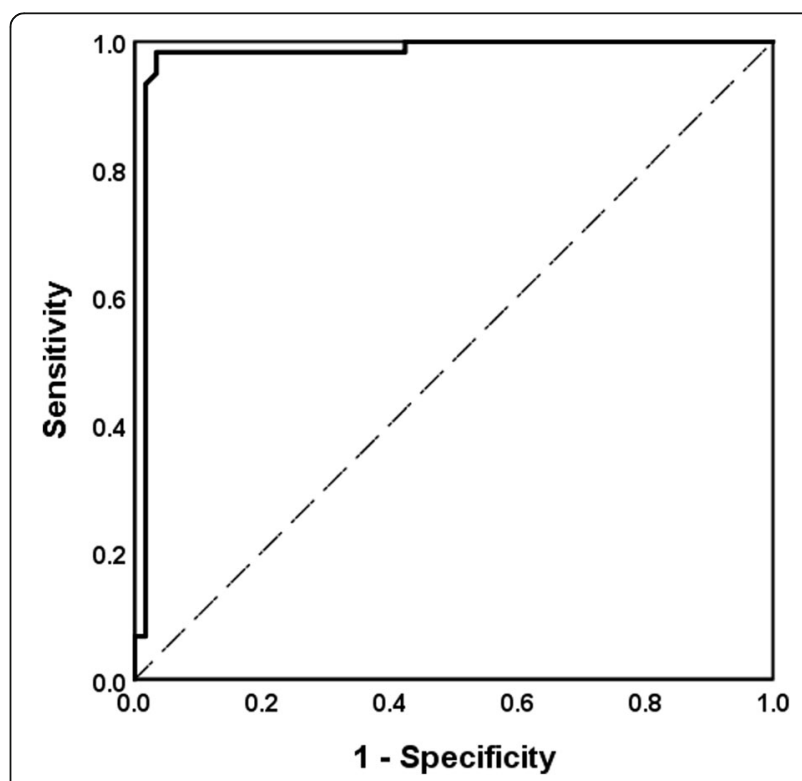

Fig. 2 Sensitivity and specificity of serum PEC index for SBP diagnosis 
Table 3 Diagnostic accuracy of PEC index and its components for SBP diagnosis and for distinguishing culture-negative SBP from sterile ascites, using ROC statistics

\begin{tabular}{|c|c|c|c|c|c|c|c|c|c|c|}
\hline \multirow{2}{*}{$\begin{array}{l}\text { Serum } \\
\text { markers }\end{array}$} & \multicolumn{5}{|l|}{ SBP diagnosis } & \multicolumn{5}{|c|}{ Discrimination between culture-negative SBP and sterile ascites } \\
\hline & Cutoff value & Sensitivity & Specificity & $\begin{array}{l}\text { AUC } \\
(95 \% \mathrm{Cl})\end{array}$ & P & Cutoff value & Sensitivity & Specificity & $\begin{array}{l}\text { AUC } \\
(95 \% \mathrm{Cl})\end{array}$ & $P$ \\
\hline $\mathrm{PCT} n g / m L$ & $>0.590$ & $81.67 \%$ & $93.33 \%$ & $\begin{array}{l}0.879 \\
0.809-0.948\end{array}$ & $<0.001$ & $>0.305$ & $85.70 \%$ & $72.90 \%$ & $\begin{array}{l}0.825 \\
0.742-0.907\end{array}$ & $<0.001$ \\
\hline ESR mm/hour & $>27.0$ & $73.33 \%$ & $61.67 \%$ & $\begin{array}{l}0.679 \\
0.581-0.776\end{array}$ & $<0.001$ & $>27.0$ & $68.60 \%$ & $61.00 \%$ & $\begin{array}{l}0.649 \\
0.521-0.776\end{array}$ & 0.008 \\
\hline CRP mg/L & $>21.0$ & $93.33 \%$ & $51.67 \%$ & $\begin{array}{l}0.736 \\
0.639-0.833\end{array}$ & $<0.001$ & $>23.5$ & $80.00 \%$ & $64.40 \%$ & $\begin{array}{l}0.704 \\
0.613-0.794\end{array}$ & $<0.001$ \\
\hline PEC index & $>20.0$ & $98.33 \%$ & $96.67 \%$ & $\begin{array}{l}0.977 \\
0.940-0.996\end{array}$ & $<0.001$ & $>20.0$ & $97.10 \%$ & $96.60 \%$ & $\begin{array}{l}0.970 \\
0.934-1.0\end{array}$ & $<0.001$ \\
\hline
\end{tabular}

$R O C$ receiver operating characteristic, $P C T$ procalcitonin, $E S R$ erythrocyte sedimentation rate, $C R P C$-reactive protein, $A U C$ area under the curve, $C I$ confidence interval

and it was significantly more elevated in culture-positive than in culture-negative cases of SBP $(P<0.001)$.

In the present study, at a cutoff value of 20 , the sensitivity and specificity of serum PEC index for SBP diagnosis $(98.33 \%$ and $96.67 \%$, respectively, AUC 0.977) were much higher than that of serum PCT, ESR, and CRP. Likewise, the sensitivity and specificity of serum PEC index, at a cutoff value of 20, to distinguish cases with culture-negative SBP from sterile ascites cases (97.1\% and $96.6 \%$, respectively, AUC 0.970), were much better than that of PEC components. The superiority of PEC index over any of its components, for diagnosis of SBP and even of its culture-negative subtype, could be explained simply by the mathematical compensatory effect of combining several markers with different degrees of

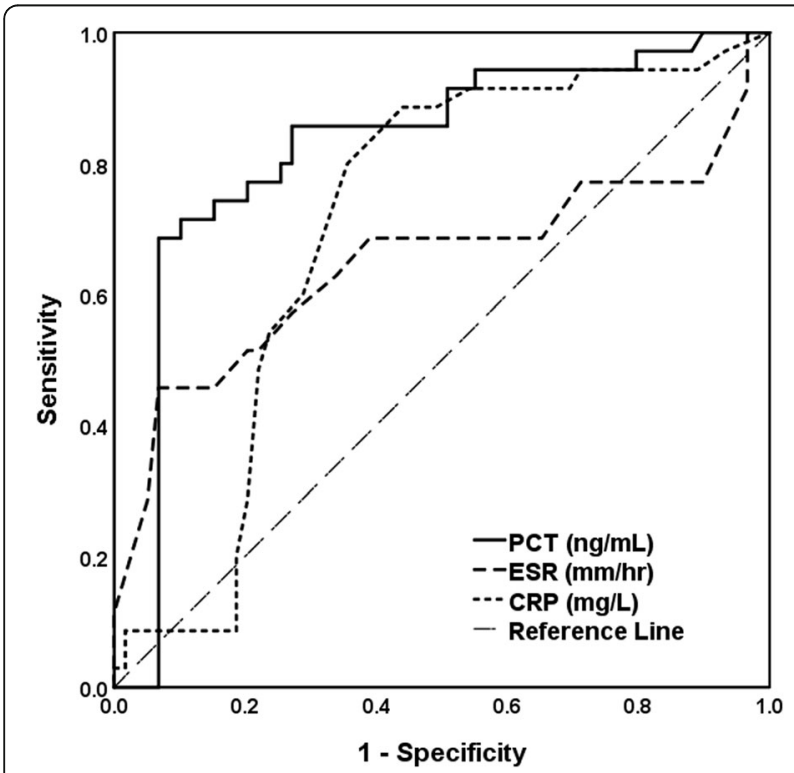

Fig. 3 Sensitivities and specificities of serum markers; ESR, CRP and $\mathrm{PCT}$ for discriminating culture-negative SBP from sterile ascites sensitivity and specificity, helping escaping false positive and false negative results.

Furthermore, the above mentioned diagnostic accuracy of PEC index in SBP is better than that of other promising serum markers that were reported in the last few years [32, 33]. Although serum homocysteine had relatively high sensitivity and specificity for distinguishing SBP (95.1\% and 89.3\%, respectively; AUC 0.932) [32], it is less accurate than PEC index. A D-dimer cutoff value of $1500 \mathrm{ng} / \mathrm{mL}$ was determined optimal for ruling out SBP due to high sensitivity $(96.8 \%)$; however, this marker was not useful for confirming SBP due to low specificity (40.6\%) [33].

Similar to our study design, Wang et al. [45] have conducted a recently published study on 259 consecutive cirrhotic patients with ascites admitted to a Chinese

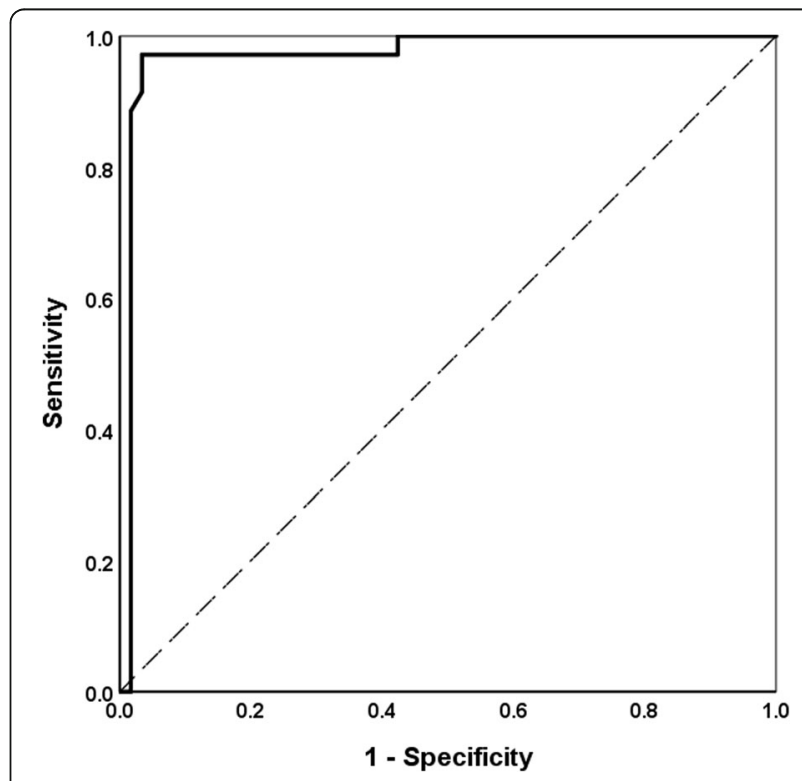

Fig. 4 Sensitivity and specificity of serum PEC index for discriminating culture-negative SBP from sterile ascites 
military hospital to investigate the efficacy in SBP diagnosis of combined measurement of PCT, mean fluorescence intensity of mature neutrophils (sNFI) and difference in hemoglobin concentration between newly formed and mature red blood cells $(\mathrm{dCHC})$. Of these, $51 / 259$ (19.7\%) had culture-positive SBP, 58/259 (22.4\%) had culture-negative SBP, and 150/259 (57.9\%) had sterile ascites. The total bioscore of those three markers used by Wang et al. [45], at a cutoff value of $\geq 3.40$, had a sensitivity of $92.6 \%$, a specificity of $95.3 \%$ and an AUC of 0.937 (95\% CI $0.901-0.994, P<0.001$ ), which are less than that of PEC index innovated in our study.

Some limitations to our study are to be mentioned. First is the relatively small sample size. Second, we did not test for serum markers other than PEC index components to help making head to head comparison. Finally, it would have been more appropriate if we added one more group of DCPs with infections other than SBP to assess specificity of PEC index for SBP.

\section{Conclusion}

The novel serum PEC index seems sufficient to make a fairly accurate non-invasive diagnosis of SBP in cirrhotic patients with ascites, provided that non-SBP bacterial infections are excluded.

\section{Recommendations}

To validate the clinical use of serum PEC index for SBP diagnosis, further larger trials are needed that should involve assessment of PEC index in non-SBP infections and its comparison with other serum biomarkers.

\section{Abbreviations}

AF: Ascitic fluid; AUC: Area under the curve; CRP: C-reactive protein; DCPS: Decompensated cirrhotic patients; ESR: Erythrocyte sedimentation rate; PCT: Procalcitonin; PEC index: Index of combined measurement of PCT, ESR and PCT; PMNL: Polymorphonuclear leukocytes; ROC: Receiver operating characteristic; SBP: Spontaneous bacterial peritonitis

\section{Acknowledgments}

Great thanks to all patients who accepted enrollment in the study as well as to all nursing staff and technicians who helped accomplishing this work.

\section{Authors' contributions \\ HE had selected the idea and design of the work, had contributed in the data collection and interpretation, shared in drafting the work, and had made the final revision of data. SE had contributed in the data collection and interpretation and shared in drafting the work. AM had helped in the data collection and analysis and had performed the laboratory work. All authors have read and approved the final manuscript.}

\section{Funding}

This research did not receive any specific grant or any other financial support from funding agencies in the public, commercial, or not-for-profit sectors.

\section{Availability of data and materials}

The datasets generated and/or analyzed during the current study are not publicly available due to confidential and institutional ethical issues but are available from the corresponding author on reasonable request.

\section{Ethics approval and consent to participate}

The study was conducted in accordance with the ethical principles of the 1975 Declaration of Helsinki, and it was reviewed and approved by Research Ethics Committee of Faculty of Medicine, Zagazig University Institutional Review Board, \#5644, in 9 March 2019. A written informed consent was obtained from all the participants after explaining the aim and concerns of the study.

Consent for publication

Not applicable.

\section{Competing interests}

The authors declare that they have no competing interests.

\section{Author details}

${ }^{1}$ Gastroenterology \& Hepatology Unit, Internal Medicine Department, Faculty of Medicine, Zagazig University, Zagazig, Egypt. ${ }^{2}$ Tropical Medicine Department, Faculty of Medicine, Zagazig University, Zagazig, Egypt. ${ }^{3}$ Clinical Pathology Department, Faculty of Medicine, Zagazig University, Zagazig, Egypt.

Received: 4 October 2019 Accepted: 23 January 2020

Published online: 16 March 2020

\section{References}

1. Wiest R, Krag A, Gerbes A (2012) Spontaneous bacterial peritonitis: recent guidelines and beyond. Gut 61:297-310

2. Acharya SK (2013) Difficult to treat spontaneous bacterial peritonitis. Trop Gastroenterol 34:7-13

3. Jalan R, Fernandez J, Wiest R, Schnabl B, Moreau R, Angeli P et al (2014) Bacterial infections in cirrhosis: a position statement based on the EASL Special Conference 2013. J Hepatol 60:1310-1324

4. Evans LT, Kim WR, Poterucha JJ, Kamath PS (2003) Spontaneous bacterial peritonitis in asymptomatic outpatients with cirrhotic ascites. Hepatology 37:897-901

5. Nousbaum JB, Cadranel JF, Nahon P, Nguyen Khac E, Moreau R, Thévenot T et al (2007) Diagnostic accuracy of the Multistix 8 SG reagent strip in diagnosis of spontaneous bacterial peritonitis. Hepatology 45:1275-1281

6. Kalaitzakis E, Johansson J (2006) Intestinal permeability in cirrhotic patients with and without ascites. Scand J Gastroenterol 41:326-330

7. Gines P, Fernandez J, Durand F, Saliba F (2012) Management of critically-ill cirrhotic patients. J Hepatol 56(Suppl 1):S13-S24

8. Wiest R, Lawson M, Geuking M (2014) Pathological bacterial translocation in liver cirrhosis. J Hepatol 60:197-209

9. Tandon P, Garcia-Tsao G (2008) Bacterial infections, sepsis, and multiorgan failure in cirrhosis. Semin Liver Dis 28:26-42

10. Garcia-Tsao G (2001) Current management of the complications of cirrhosis and portal hypertension: variceal hemorrhage, ascites, and spontaneous bacterial peritonitis. Gastroenterology 120:726-748

11. Piddock L, Planas R, Bernard B, Inadomi JM (2000) Diagnosis, treatment and prophylaxis of spontaneous bacterial peritonitis: a consensus document. International ascites club. J Hepatol 32(1):142-153

12. Fernandez J, Navasa M (2002) Bacterial infections in cirrhosis: epidemiological changes with invasive procedures and norfloxacin prophylaxis. Hepatology 35:140-148

13. Wong CL, Holroyd-Leduc J (2008) Does this patient have bacteria peritonitis or portal hypertension? How do I perform a paracentesis and analyze the results? JAMA 299:1166-1178

14. European Association for the Study of the Liver (2010) EASL clinical practice guidelines on the management of ascites, spontaneous bacterial peritonitis, and hepatorenal syndrome in cirrhosis. J Hepatol 53:397-417

15. Runyon BA, AASLD (2013) Introduction to the revised American Association for the Study of Liver Diseases Practice Guideline management of adult patients with ascites due to cirrhosis 2012. Hepatology 57:1651-1653

16. Attar BM, George M (2014) Disease dependent qualitative and quantitative differences in the inflammatory response to ascites occurring in cirrhotics. World J Hepatol 6:85-91

17. Wehmeyer MH, Krohm S, Kastein F, Lohse AW, Lüth S (2014) Prediction of spontaneous bacterial peritonitis in cirrhotic ascites by a simple scoring system. Scand J Gastroenterol 49:595-603 
18. Gundling F, Schmidtler F, Hapfelmeier A, Schulte B, Schmidt T, Pehl C et a (2011) Fecal calprotectin is a useful screening parameter for hepatic encephalopathy and spontaneous bacterial peritonitis in cirrhosis. Liver Int 31:1406-1415

19. Kim JK, Chon CY, Kim JH, Kim YJ, Cho JH, Bang SM et al (2007) Changes in serum and ascitic monocyte chemotactic protein-1 (MCP-1) and IL-10 levels in cirrhotic patients with spontaneous bacterial peritonitis. J Interf Cytokine Res 27:227-230

20. Gong Y, Cui S, Li L, Wang M, Guo N (2013) Diagnostic value of human neutrophil peptide in spontaneous bacterial peritonitis. Chin J Hepatol 21: 944-948 [abstract]

21. Abdel-Razik A, Eldars W, Rizk E (2014) Platelet indices and inflammatory markers as diagnostic predictors for ascitic fluid infection. Eur J Gastroenterol Hepatol 26:1342-1347

22. Lesińska M, Hartleb M, Gutkowski K, Nowakowska-Duława E (2014) Procalcitonin and macrophage inflammatory protein-1 beta (MIP-1 $\beta$ ) in serum and peritoneal fluid of patients with decompensated cirrhosis and spontaneous bacterial peritonitis. Adv Med Sci 59:52-56

23. Abdel-Razik A, Mousa N, Elbaz S, Eissa M, Elhelaly R, Eldars W (2015) Diagnostic utility of interferon gamma-induced protein $10 \mathrm{kDa}$ in spontaneous bacterial peritonitis: single-center study. Eur J Gastroenterol Hepatol 27:1087-1093

24. Uzzan B, Cohen R, Nicolas P, Cucherat M, Perret GY (2006) Procalcitonin as a diagnostic test for sepsis in critically ill adults and after surgery or trauma: a systematic review and meta-analysis. Crit Care Med 34(7):1996-2003

25. O'Grady NP, Barie PS, Bartlett JG, Bleck T, Carroll K, Kalil AC et al (2008) Guidelines for evaluation of new fever in critically ill adult patients: 2008 update from the American College of Critical Care Medicine and the Infectious Diseases Society of America. Crit Care Med 36(4):1330-1349

26. Wacker C, Prkno A, Brunkhorst FM, Schlattmann P (2013) Procalcitonin as a diagnostic marker for sepsis: a systematic review and meta-analysis. Lancet Infect Dis 13(5):426-435

27. Yang SK, Xiao L, Zhang H, Xu XX, Song PA, Liu FY, Sun L (2014) Significance of serum procalcitonin as biomarker for detection of bacterial peritonitis: a systematic review and meta-analysis. BMC Infect Dis 14:452

28. Cai ZH, Fan CL, Zheng JF, Zhang X, Zhao WM, Li B et al (2015) Measurement of serum procalcitonin levels for the early diagnosis of spontaneous bacterial peritonitis in patients with decompensated liver cirrhosis. BMC Infect Dis 15:55

29. Yang Y, Li L, Qu C, Zeng B, Liang S, Luo Z, Wang X, Zhong C (2015) Diagnostic accuracy of serum procalcitonin for spontaneous bacterial peritonitis due to end-stage liver disease: a meta-analysis. Medicine (Baltimore) 94(49):e2077

30. Abdel-Razik A, Mousa N, Elhammady D, Elhelaly R, Elzehery R, Elbaz S et al (2016) Ascitic fluid calprotectin and serum procalcitonin as accurate diagnostic markers for spontaneous bacterial peritonitis. Gut Liver 10(4):624-631

31. Kim SU, Kim DY, Lee CK, Park JY, Kim SH, Kim HM et al (2010) Ascitic fluid infection in patients with hepatitis B virus-related liver cirrhosis: culturenegative neutrocytic ascites versus spontaneous bacterial peritonitis. J Gastroenterol Hepatol 25(1):122-128

32. Abdel-Razik A, Eldars W, Elhelaly R, Eldeeb AA, Abdelsalam M, El-Wakeel N, Aboulmagd A (2018) Homocysteine a new diagnostic marker in spontaneous bacterial peritonitis. Eur J Gastroenterol Hepatol 30(7):779-785

33. Mikuła T, Sapuła M, Jabłońska J, Kozłowska J, Stańczak W, Krankowska D, Wiercińska-Drapało A (2018) Significance of heparin-binding protein and Ddimers in the early diagnosis of spontaneous bacterial peritonitis. Mediat Inflamm 2018:2018

34. Badawy AA, Zaher TI, Sharaf SM, Emara MH, Shaheen NE, Aly TF (2013) Effect of alternative antibiotics in treatment of cefotaxime resistant spontaneous bacterial peritonitis. World J Gastroenterol 19(8):1271

35. El Motasem EM, Heikal AA, El Haddad HE, Hamdy A, Samie RM, El Din HS (2015) Value of different diagnostic markers in spontaneous bacterial peritonitis in HCV Egyptian cirrhotic patients. Open J Gastroenterol 5(09):119

36. Viallon A, Zeni F, Pouzet V, Lambert C, Quenet S, Aubert G et al (2000) Serum and ascitic procalcitonin levels in cirrhotic patients with spontaneous bacterial peritonitis: diagnostic value and relationship to pro-inflammatory cytokines. Intensive Care Med 26(8):1082-1088

37. Such J, Hillebrand DJ, Guarner C, Berk L, Zapater P. Westengard J et a (2001) Tumor necrosis factor-a, interleukin-6, and nitric oxide in sterile ascitic fluid and serum from patients with cirrhosis who subsequently develop ascitic fluid infection. Digest Dis Sci 46(11):2360-2366
38. Papp M, Vitalis Z, Altorjay I, Tornai I, Udvardy M, Harsfalvi J et al (2012) Acute phase proteins in the diagnosis and prediction of cirrhosis associated bacterial infections. Liver Int 32(4):603-611

39. Wu H, Chen L, Sun Y, Meng C, Hou W (2016) The role of serum procalcitonin and $\mathrm{C}$-reactive protein levels in predicting spontaneous bacterial peritonitis in patients with advanced liver cirrhosis. Pak J Med Sci 32(6):1484-1488

40. Deschénes M, Villeneuve JP (1999) Risk factors for the development of bacterial infections in hospitalized patients with cirrhosis. Am J Gastroenterol 94:2193-2197

41. Luzzani A, Polati E, Dorizzi R, Rungatscher A, Pavan R, Merlini A (2003) Comparison of procalcitonin and C-reactive protein as markers of sepsis. Crit Care Med 31(6):1737-1741

42. Lata J, Stiburek O, Kopacova M (2009) Spontaneous bacterial peritonitis: a severe complication of liver cirrhosis. World J Gastroenterol 15(44):5505

43. Cekin Y, Cekin AH, Duman A, Yilmaz U, Yesil B, Yolcular BO (2013) The role of serum procalcitonin levels in predicting ascitic fluid infection in hospitalized cirrhotic and non-cirrhotic patients. Int J Med Sci 10(10):1367-1374

44. El-Gendy NA, Tawfeek NA, Saleh RA, Radwan EE, Ahmad EE, Mohammed RA (2014) Diagnosis of spontaneous bacterial peritonitis. Egypt J Intern Med 26(2):53

45. Wang H, Li Y, Zhang F, Yang N, Xie N, Mao Y, Li B (2018) Combination of $\mathrm{PCT}, \mathrm{sNFI}$ and $\mathrm{dCHC}$ for the diagnosis of ascites infection in cirrhotic patients. BMC Infect Dis 18(1):389

\section{Publisher's Note}

Springer Nature remains neutral with regard to jurisdictional claims in published maps and institutional affiliations.

\section{Submit your manuscript to a SpringerOpen ${ }^{\circ}$ journal and benefit from:}

- Convenient online submission

- Rigorous peer review

- Open access: articles freely available online

- High visibility within the field

- Retaining the copyright to your article

Submit your next manuscript at $>$ springeropen.com 